Original Article

Artigo Original

Renata Paula de Almeida ${ }^{1}$

Carla Gentile Matas ${ }^{1}$

Maria Inês Vieira Couto ${ }^{1}$

Ana Claudia Martinho de Carvalho ${ }^{1}$

Keywords

Cochlear Implantation Quality of Life

Hearing

Child

Hearing Loss

Descritores

Implante Coclear

Qualidade de Vida

Audição

Criança

Perda Auditiva

Correspondence address:

Ana Claudia Martinho de Carvalho

Rua Cipotânia, 51, São Paulo (SP),

Brazil, CEP: 05360-160.

E-mail: anacmartinho@usp.br

Received: 08/08/2014

Accepted on: 12/12/2014

\section{Quality of life evaluation in children \\ with cochlear implants}

\author{
Avaliação da qualidade de vida em crianças \\ usuárias de implante coclear
}

\begin{abstract}
Purpose: To evaluate the quality of life of children with cochlear implants from the perspective of their parents. Methods: A clinical and cross-sectional study was conducted with 15 parents of children using cochlear implants of both genders aged between 2 and 12 years old. Parents of these children answered the questionnaire "Children with Cochlear Implants: Parental Perspective" (CCIPP). Data related to auditory category and time of cochlear implants use were collected from medical records of the children. The percentages of responses on the CCIPP domains were tabulated and descriptively and inferentially analyzed. Results: The cochlear implants had a positive effect on the quality of life of children in the self-reliance (58.9\%) and social relationships (56.7\%) domains. No correlation was observed between the time of cochlear implants activation (months) and any of the CCIPP domains. However, children with 24 months or less of cochlear implant use presented higher percentages on the communication domain than those with more than 24 months of cochlear implants use. A negative correlation was observed between the auditory category and the effects of the implant domain. Conclusion: From the perspective of parents, the use of cochlear implants improves the quality of life of their children; the shorter the time of cochlear implants use, the higher the improvement in quality of life; and the more developed the auditory skills, the lower the percentage of quality of life improvement with the cochlear implants.
\end{abstract}

\section{RESUMO}

Objetivo: Avaliar a qualidade de vida de crianças usuárias de implante coclear sob a perspectiva de seus pais. Métodos: Estudo clínico e transversal com 15 pais de crianças usuárias de implante coclear, de ambos os gêneros e com idades entre 2 e 12 anos. Os pais responderam ao questionário "Crianças com Implante Coclear: Perspectiva dos Pais" (CCIPP). Foram levantados, nos prontuários das crianças, os dados referentes à categoria de audição e tempo de uso do dispositivo. Os percentuais dos domínios do CCIPP foram tabulados e analisados de forma descritiva e inferencial. Resultados: Os domínios do questionário de qualidade de vida que apresentaram maior média foram autoconfiança $(58,9 \%)$ e relações sociais $(56,7 \%)$. Não foi verificada correlação entre o tempo (meses) de uso do implante coclear e os domínios do questionário. No entanto, as crianças com tempo de uso inferior ou igual a 24 meses apresentaram maior percentual no domínio comunicação do que aquelas com tempo de uso superior a 24 meses. Houve correlação negativa entre a categoria de audição e o domínio efeitos do implante. Conclusão: Na perspectiva dos pais, o uso do implante coclear melhora a qualidade de vida de seus filhos. Quanto menor o tempo de uso do implante coclear, maior o percentual da qualidade de vida; e, quanto mais desenvolvida a habilidade auditiva, menor o percentual de melhora da qualidade de vida.

Study carried out at Speech and Hearing Therapy Laboratory for Educational Audiology, Department of Physical Therapy, Speech Language Pathology and Audiology, and Occupational Therapy, Medical School, Universidade de São Paulo - USP - São Paulo (SP), Brazil.

(1) Department of Physical Therapy, Speech Language Pathology and Audiology, and Occupational Therapy, Medical School, Universidade de São Paulo - USP - São Paulo (SP), Brazil.

Financial support: Fundação de Amparo à Pesquisa do Estado de São Paulo - FAPESP.

Conflict of interests: nothing to declare. 


\section{INTRODUCTION}

Hearing loss causes difficulties in the ability of understanding speech sounds and, hence, results in social and family withdrawal, low self-esteem, isolation, loneliness, depression, and irritability. All these factors affect the quality of life (QoL), for they impair socialization and the individual's participation in the group the person belongs to ${ }^{(1)}$.

Severe and/or bilateral profound sensorineural hearing loss has been long regarded as a change that does not allow the individual to communicate or even identify environmental sounds such as alarms and sirens, which limits their social activities. Currently, electronic devices aimed to deafness have been developed, and technology is being constantly improved in an effort to enhance communication skills and, thus, contribute to a better QoL for these people ${ }^{(2)}$.

Among technologies that have emerged to provide accessibility to environmental and speech sounds in the hearing-impaired population is cochlear implant (CI). This sophisticated-technology device is a computerized prosthesis composed of an internal and an external component able to partially replace the sensory hearing organ, providing electrical inputs that stimulate the remaining nerve fibers of the cochlea ${ }^{(3)}$.

The performance obtained in the auditory and language skills alone is not sufficient to justify the variation of results in infant users of this device. Outcomes obtained in clinical evaluation are not always related to the performance in situations others than the clinical context $\mathrm{t}^{(4,5)}$.

The need to use a measure that can evaluate the range of aspects that contribute to the benefits obtained from the use of IC, and to the development of hearing and speech skills, has motivated researchers to use QoL measures.

The group of Quality of Life from the World Health Organization (WHOQOL) defines QoL as "the self-perception of an individual's position in life in the context of culture and value systems and in relation to their goals, expectations, standards and concerns"(6). The QoL assessment brings important information about treatment effectiveness and how it interferes with families' dynamics.

Therefore, the QoL questionnaires emerged as a tool to assess results obtained after the CI surgery ${ }^{(7,8)}$. Such instruments subjectively assess the multifactor impact (areas) of CI users' health conditions.

The impact of CI in children and adolescents with severe or profound hearing loss goes beyond improvements in the perception and production of speech and language development, thus encompassing physical and mental health, that is, QoL. Specific questionnaires for subjects with CI, aspects such as hearing and comfort in some environments, time of CI use, limitations in activities, and feelings of frustration and embarrassment must be added to gather as much information as possible (clinical benefits) and allow correlations between topics (scientific benefits) ${ }^{(9)}$.

Results of the questionnaires, from the perspective of parents, have the advantage of providing a method applicable to children of all ages, based on the account of people involved in the process and CI outcomes. Parents can provide information on a variety of situations to which children are exposed, such as school, daily routines, and the familial relationship, enabling a description of CI outcomes in children through a single instrument ${ }^{(10,11)}$.

Moreover, parents can provide good evaluation of the process of therapeutic intervention evolution with their children. Their satisfaction is a marker for the development of children and shows that CI reaches or exceeds intervention expectations ${ }^{(12,13)}$.

Although CI provides access to speech sounds, and hearing (re)habilitation is an interactive process that minimizes or prevents limitations and restrictions that hearing loss may impose on well-being and communication ${ }^{(14)}$, including interpersonal, psychological, educational, and vocational features, it is very important that the audiologist understand what and how domains, from the perspective of parents, change by CI use.

The objective of this study was to evaluate the QoL of children with CI from the perspective of their parents to verify whether features related to these children and their families' QoL are related to CI use and to the development of hearing skills.

\section{METHODS}

This is a cross-sectional descriptive study approved by the research ethics committee of the Medical School of Universidade de São Paulo (No. 388/11). All parents signed the informed consent form.

Parents and their children with CI participated in the study; they were all from both genders aged from 2 to 12 years old.

Selection of participants was made by the assessment of medical records of children with CI at Speech and Hearing Therapy Laboratory for Educational Audiology, Department of Physical, Speech, and Occupational Therapy, Medical School, Universidade de São Paulo, São Paulo, Brazil. After selection, parents were invited to participate in the study.

Inclusion criteria were effective use of CI of not less than 6 months and speech therapy attendance in the period of data collection in this laboratory, whose therapeutic approach follows the guiding principles of aurioral approach $^{(15)}$. Children with other disabilities (neurological and behavioral) associated with hearing impairment were excluded.

The study group consisted of 15 parents (14 mothers and one father). Mean age of children in the data collection period was 90.5 months (range 18-146 months); mean age upon CI activation was 54.4 months (range 11-98 months) and the average use of CI was 35.7 months (range 6-77 months).

Information on the development of listening skills was collected from medical records of each patient. Results found in the adapted test Glendonald Auditory Screening 
Procedure (GASP) ${ }^{(16)}$ were used to classify hearing skills, as this speech perception test comprises six tests contemplating different hearing skills (detection, discrimination, recognition, and comprehension) and enables the assessment of children with different ages and different levels of hearing development.

The analysis was based on the nature of skills and classified according to hearing categories ${ }^{(17)}$ as follows: 0 - speech not detected; 1 - detection; 2 - pattern of perception; 3 - initiating word identification; 4 - word identification by vowel sound recognition; 5 - word identification by consonant sound recognition; 6 - word recognition in an open setting.

To assess QoL, the questionnaire "Children with Cochlear Implants: Parental Perspective (CCIPP)" was used $^{(18)}$, a specific tool for the pediatric population using CI. This instrument was translated and culturally adapted to Brazilian Portuguese as "Crianças com Implante Coclear: Perspectiva dos Pais" (19).

The CCIPP consists of 74 statements (46 worded positively and 28 negatively), which cover the following areas: communication (5 items), general functioning (5 items), self-confidence (4 items), well-being and happiness (5 items), social relations (8 items), education (8 items), implant process (16 items), implant effects (6 items), decision of implant (10 items), and child support (7 items). The answers are multiple-choice type in a fivescore scale: strongly agree (5); agree (4); neither agree nor disagree (3); disagree (2); and strongly disagree (1).

The CCIPP was applied individually to parents by the examiner, who had had no prior contact with the children to avoid influence in data collection. The 74 statements were read to children's caregivers, who were supposed to point to a card with one of the earlier-mentioned five alternatives. The average time of survey application was 30 minutes.

Scores for each statement were noted down on a report sheet and later typed in the database Parent Views and Experiences Questionnaire Data Entry (version 1.02; ISVR Software, Copyright 2003), created by the staff of Ear Foundation (http://www.earfoundation.org.uk/).

The software assigns to each statement a percentage value. The more positive the value assigned, the greater the relationship between the use of CI and better QoL in each domain assessed. The more negative the value, the lower the ratio between the use of the device and QoL from the parents' perspective.

The software, developed to analyze data from CCIPP protocol, analyzes 8 of 10 existing domains of the questionnaire. Domains "decision of implant" (16 issues) and "process of implant" (10 issues) are not included in the analysis, for, according to the authors of the survey, these are items that can only be assessed qualitatively.

Therefore, this study will present only quantitative results of the following areas: communication, general functioning, self-confidence, well-being and happiness, social relations, education, implant outcomes, and child support.
To better understand the results of CI use and of hearing skills development (hearing categories) with the domains of the QoL questionnaire in children using CI, subgroups were established, considering the number of subjects in each group possible for an inferential statistical analysis: time of CI use not exceeding 24 months and over 24 months; and hearing categories 2 and 3 .

The percentages of each domain were statistically analyzed using SPSS software, version 18. A descriptive analysis of the areas involved was performed (mean, standard deviation, minimum, maximum, median, and first and third quartiles). Inferential analysis was performed with Spearman's correlation coefficient (correlation between domains) and the Mann-Whitney test (interference of CI use and hearing category in the general group and subgroups). Significance level was set at 5\%, and significant values were marked with an asterisk.

\section{RESULTS}

As to hearing category, $1(6.7 \%)$ child fitted category 5 , $6(40 \%)$ children in category $3,6(40 \%)$ in category 2 , and $2(13.3 \%)$ in category 1.

On average, from the perspective of parents, CI has improved the QoL of 15 children in all areas relating to children and in one of the domains related to family. Among the domains of QoL questionnaire, self-confidence $(58.9 \%)$ and social relations $(56.7 \%)$ had higher mean values. In contrast, child support $(-10.0 \%)$ and effects of the implant $(8.0 \%)$ had lower mean values (Figure 1). In some cases, some results of QoL were away from the mean value of the group (Figure 1).

Parents of children 1 and 8 reported that they "had delayed development in oral language, making communication difficult even with the family" and, therefore, the CI had not offered an improvement in the field of communication yet. Parents of children aged 4 and 13 years old reported that their children were "unable to perform activities by themselves," which reflects a less positive perspective for the self-confidence domain. Parents of children aged 2 and 10 years old did not report improvement in well-being and happiness, for they reported "feeling of frustration before CI activation." On the other hand, a mother of a child aged 7 associated CI use to an improvement in well-being and happiness. The father of a child aged 15 reported that he could not measure the impact of the $\mathrm{CI}$ in social relations because of his child's age group (24 months).

Analysis between QoL domains showed a negative correlation between social relations and well-being/happiness only $(\mathrm{p}=0.046)$ (Table 1$)$.

No correlation between CI time of use (months) and QoL domains was found. However, a negative correlation was observed between hearing category and implant outcomes $(\mathrm{p}=0.050)($ Table 2).

The subgroup of children with CI time of use not exceeding 24 months consisted of seven children, whose 
average time of use was $15.1( \pm 7.5)$ months. The group with time of use longer than 24 months consisted of 8 subjects, with mean time of use of $53.8( \pm 19.1)$ months. Comparative analysis showed differences between groups only as to communication $(\mathrm{p}=0.035)$, with higher percentage in the group using CI for 24 months at most (Table 3 ).

When comparisons were made with hearing category, only 12 children, who were in categories 2 and 3, were considered; the number of children in other hearing categories $(n=3)$ was insufficient for inferential statistical analysis

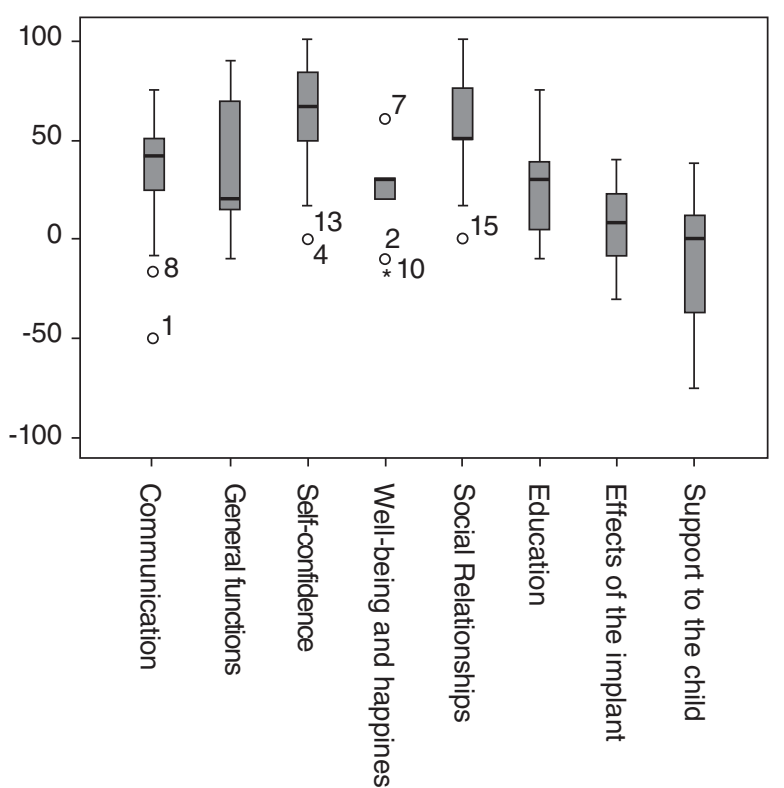

Figure 1. Boxplot chart with mean scores in all quality of life domains
Each subgroup was composed of six children. Those who were in category 2 had mean CI time of use of $39.5( \pm 27.9)$ months, whereas children who belonged to hearing category 3 subgroup mean time of use of $44.2( \pm 20.4)$ months. The comparative analysis showed differences between the groups only in the field of implant outcomes $(p=0.037)$, with better percentage in category 2 group (Table 4).

\section{DISCUSSION}

This study aimed to evaluate QoL after CI activation in 15 children from the perspective of their parents and to examine possible correlations between the QoL different domains, time of CI use, and the development of hearing skills. QoL is widely influenced by $\mathrm{CI}^{(20-24)}$.

Parents' view can add significant value to the evaluations obtained by professionals because they can provide valuable information on the child's auditory and language development, implantation process, other necessary interventions, and the benefits and limitations experienced. Applying a questionnaire to parents reflects the view of people deeply interested in the process and results after CI activation in children of different age groups ${ }^{(25)}$.

It is known that QoL among children and adolescents who use CI is similar to that of their listener counterparts ${ }^{(26)}$. Thus, the population of children using CI, the use of questionnaires with parents allows us to check children's QoL, as well as their parents' and relatives', or the interaction between all of them ${ }^{(27)}$.

According to the results of this study, CI had a positive effect on the QoL of children and their families. All

Table 1. Spearman's correlation coefficient between domains of quality of life questionnaire

\begin{tabular}{|c|c|c|c|c|c|c|c|}
\hline & Communication & $\begin{array}{c}\text { General } \\
\text { functioning }\end{array}$ & $\begin{array}{c}\text { Self- } \\
\text { confidence }\end{array}$ & $\begin{array}{c}\text { Well-being and } \\
\text { happiness }\end{array}$ & Social relations & Education & $\begin{array}{l}\text { Implant } \\
\text { outcomes }\end{array}$ \\
\hline \multicolumn{8}{|c|}{ General functioning } \\
\hline rho & 0.363 & & & & & & \\
\hline \multicolumn{8}{|c|}{ Self-confidence } \\
\hline rho & 0.317 & 0.335 & & & & & \\
\hline rho & -0.038 & 0.081 & -0.162 & & & & \\
\hline$p$ & 0.893 & 0.774 & 0.565 & & & & \\
\hline \multicolumn{8}{|c|}{ Social relations } \\
\hline rho & 0.026 & 0.019 & 0.293 & -0.522 & & & \\
\hline$p$ & 0.927 & 0.948 & 0.290 & $0.046^{*}$ & & & \\
\hline rho & 0.401 & -0.051 & 0.049 & -0.191 & -0.188 & -0.108 & \\
\hline$p$ & 0.139 & 0.857 & 0.862 & 0.495 & 0.502 & 0.702 & \\
\hline \multicolumn{8}{|c|}{ Child support } \\
\hline rho & 0.431 & 0.241 & 0.366 & -0.302 & 0.348 & 0.351 & 0.414 \\
\hline$p$ & 0.108 & 0.388 & 0.180 & 0.274 & 0.204 & 0.199 & 0.125 \\
\hline
\end{tabular}

*Significant values $(p \leq 0.05)$, Spearman's correlation coefficient 
Table 2. Spearman's correlation coefficient between domains of quality of life questionnaire and variables time (months) of cochlear implant activation and hearing category

\begin{tabular}{|c|c|c|c|c|c|c|c|c|}
\hline & Communication & $\begin{array}{c}\text { General } \\
\text { functioning }\end{array}$ & $\begin{array}{c}\text { Self- } \\
\text { confidence }\end{array}$ & $\begin{array}{c}\text { Well-being and } \\
\text { happiness }\end{array}$ & $\begin{array}{c}\text { Social } \\
\text { relations }\end{array}$ & Education & $\begin{array}{c}\text { Implant } \\
\text { outcomes }\end{array}$ & $\begin{array}{c}\text { Child } \\
\text { support }\end{array}$ \\
\hline \multicolumn{9}{|c|}{ Time of cochlear } \\
\hline \multicolumn{9}{|c|}{ implant use } \\
\hline rho & -0.435 & 0.209 & -0.078 & -0.259 & 0.178 & -0.425 & 0.043 & 0.033 \\
\hline $\mathrm{p}$ & 0.105 & 0.455 & 0.781 & 0.351 & 0.526 & 0.114 & 0.878 & 0.908 \\
\hline \multicolumn{9}{|c|}{ Hearing categories } \\
\hline rho & 0.062 & 0.422 & 0.152 & 0.177 & 0.246 & -0.096 & -0.515 & -0.003 \\
\hline $\mathrm{p}$ & 0.826 & 0.117 & 0.590 & 0.528 & 0.376 & 0.732 & $0.050^{*}$ & 0.992 \\
\hline
\end{tabular}

*Significant values $(p \leq 0.05)$, Spearman's correlation coefficient

Table 3. Comparison between performances in each quality of life domain and the time (24 months) of cochlear implants activation

\begin{tabular}{|c|c|c|c|c|c|c|c|c|c|c|}
\hline Group & Mean & $\begin{array}{l}\text { Standard } \\
\text { deviation }\end{array}$ & Minimum & Maximum & $\begin{array}{c}\text { First } \\
\text { quartile }\end{array}$ & Median & $\begin{array}{c}\text { Third } \\
\text { quartile }\end{array}$ & $U$ & $Z$ & $p$-value \\
\hline \multicolumn{11}{|l|}{ Communication } \\
\hline$<24$ months & 47.62 & 27.094 & -8.3 & 75.0 & 41.7 & 50.0 & 66.7 & \multirow{2}{*}{10.0} & \multirow{2}{*}{-2.110} & \multirow{2}{*}{$0.035^{*}$} \\
\hline >24 months & 18.75 & 35.003 & -50.0 & 50.0 & -8.3 & 33.3 & 45.8 & & & \\
\hline \multicolumn{11}{|c|}{ General functioning } \\
\hline$<24$ months & 37.14 & 30.394 & 10.0 & 90.0 & 10.0 & 20.0 & 60.0 & \multirow{2}{*}{24.5} & \multirow{2}{*}{-0.411} & \multirow{2}{*}{0.681} \\
\hline$>24$ months & 43.75 & 37.773 & -10.0 & 90.0 & 12.5 & 45.0 & 77.5 & & & \\
\hline \multicolumn{11}{|l|}{ Self-confidence } \\
\hline$<24$ months & 57.14 & 40.662 & 0.0 & 100.0 & 0.0 & 66.7 & 83.3 & \multirow{2}{*}{25.0} & \multirow{2}{*}{-0.358} & \multirow{2}{*}{0.721} \\
\hline$>24$ months & 60.42 & 21.706 & 16.7 & 83.3 & 50.0 & 66.7 & 79.2 & & & \\
\hline$<24$ months & 18.57 & 23.401 & -20.0 & 40.0 & -10.0 & 30.0 & 30.0 & \multirow{2}{*}{27.5} & \multirow{2}{*}{-0.060} & \multirow{2}{*}{0.953} \\
\hline$>24$ months & 27.50 & 15.811 & 10.0 & 60.0 & 20.0 & 20.0 & 37.5 & & & \\
\hline \multicolumn{11}{|l|}{ Social relations } \\
\hline$<24$ months & 53.57 & 19.753 & 16.7 & 75.0 & 50.0 & 50.0 & 75.0 & \multirow{2}{*}{25.0} & \multirow{2}{*}{-0.355} & \multirow{2}{*}{0.722} \\
\hline$>24$ months & 59.38 & 34.272 & 0.0 & 100.0 & 35.0 & 60.0 & 93.8 & & & \\
\hline \multicolumn{11}{|l|}{ Education } \\
\hline$<24$ months & 36.07 & 24.911 & 0.0 & 75.0 & 20.0 & 30.0 & 60.0 & \multirow{2}{*}{16.5} & \multirow{2}{*}{-1.343} & \multirow{2}{*}{0.179} \\
\hline$>24$ months & 16.25 & 19.226 & -10.0 & 40.0 & 0.0 & 15.0 & 37.5 & & & \\
\hline \multicolumn{11}{|c|}{ Implant outcomes } \\
\hline$<24$ months & 10.95 & 15.717 & -8.3 & 33.3 & -8.3 & 10.0 & 25.0 & \multirow{2}{*}{24.0} & \multirow{2}{*}{-0.465} & \multirow{2}{*}{0.642} \\
\hline$>24$ months & 5.42 & 24.828 & -30.0 & 40.0 & -17.1 & 4.2 & 30.0 & & & \\
\hline \multicolumn{11}{|l|}{ Child support } \\
\hline$<24$ months & -8.93 & 30.375 & -37.5 & 37.5 & -37.5 & -25.0 & 25.0 & \multirow{2}{*}{27.5} & \multirow{2}{*}{-0.059} & \multirow{2}{*}{0.953} \\
\hline$>24$ months & -10.94 & 40.332 & -75.0 & 37.5 & -46.9 & 0.0 & 28.1 & & & \\
\hline
\end{tabular}

*Significant difference $(p<0.05)$, Mann-Whitney test

areas relating to children had improvement in QoL after CI activation. Parents were more satisfied with the domains self-confidence and social relations, suggesting that the hearing ability provided by CI, associated with the development of hearing and language skills, brought a positive attitude and acceptance of children with regard to their skills and abilities in situations of communication and, hence, the expansion of their social relations (familial and nonfamilial).

These results corroborate studies conducted with children using CI and their families by applying the $\operatorname{CCIPP}^{(11,19)}$, in which these two domains (self-confidence and social relations) are cited among those that best represent the way CI interferes positively on users QoL.

Well-being/happiness and education had less positive impact (23.3 and $25.5 \%$, respectively). Children in this study were identified by parents as "happy" and "socially adjusted" even before the use of CI. With regard to education, parents were concerned about their children's performance, fearing that the "CI would not promote conditions of school performance in the future. They showed awareness of the fact that hearing is an important but not decisive factor for full school development and learning.

Child support and implant outcomes also relate to the family's QoL, whose percentages were considered less positive (-10 and $8 \%$, respectively). Parents showed concern at "the possibility of breaking the CI or support and monitoring loss by the center where CI was set."

Most parents reported that the effects achieved with the use of CI were below their initial expectations. They feared that "the child could not eventually develop advanced hearing and language skills," thus needing constant family support (dependence) in daily activities. This additional perspective of parents is in a way contrary to the improvement in self-confidence and social relations already conquered by their children and previously discussed. Therefore, achievements earned within a certain time after CI activation do not minimize parents' doubts 
Table 4. Comparison between performances in each quality of life domain and hearing categories

\begin{tabular}{|c|c|c|c|c|c|c|c|c|c|c|}
\hline Category & Mean & $\begin{array}{l}\text { Standard } \\
\text { deviation }\end{array}$ & Minimum & Maximum & $\begin{array}{c}\text { First } \\
\text { quartile }\end{array}$ & Median & $\begin{array}{c}\text { Third } \\
\text { quartile }\end{array}$ & $U$ & $Z$ & $\mathrm{p}$-value \\
\hline \multicolumn{11}{|c|}{ Communication } \\
\hline 2 & 31.95 & 27.090 & -16.7 & 50.0 & 8.3 & 45.8 & 50.0 & \multirow{2}{*}{16.5} & \multirow{2}{*}{-0.246} & \multirow{2}{*}{0.805} \\
\hline 3 & 26.39 & 38.878 & -50.0 & 58.3 & 12.5 & 33.3 & 52.1 & & & \\
\hline \multicolumn{11}{|c|}{ General functioning } \\
\hline 2 & 35.00 & 30.166 & -10.0 & 70.0 & 12.5 & 35.0 & 62.5 & \multirow{2}{*}{14.5} & \multirow{2}{*}{-0.566} & \multirow{2}{*}{0.571} \\
\hline 3 & 46.67 & 37.238 & 10.0 & 90.0 & 10.0 & 45.0 & 82.5 & & & \\
\hline \multicolumn{11}{|c|}{ Self-confidence } \\
\hline 2 & 66.67 & 25.817 & 16.7 & 83.3 & 54.2 & 75.0 & 83.3 & \multirow{2}{*}{10.5} & \multirow{2}{*}{-1.248} & \multirow{2}{*}{0.212} \\
\hline 3 & 52.78 & 28.707 & 0.0 & 83.3 & 37.5 & 58.3 & 70.8 & & & \\
\hline \multicolumn{11}{|c|}{ Well-being and happiness } \\
\hline 2 & 11.67 & 23.166 & -20.0 & 40.0 & -12.5 & 15.0 & 32.5 & \multirow{2}{*}{9.5} & \multirow{2}{*}{-1.391} & \multirow{2}{*}{0.164} \\
\hline 3 & 31.67 & 16.021 & 20.0 & 60.0 & 20.0 & 25.0 & 45.0 & & & \\
\hline \multicolumn{11}{|c|}{ Social relations } \\
\hline 2 & 48.61 & 36.672 & 0.0 & 100.0 & 12.5 & 50.0 & 81.3 & \multirow{2}{*}{14.0} & \multirow{2}{*}{-0.654} & \multirow{2}{*}{0.513} \\
\hline 3 & 62.50 & 24.444 & 30.0 & 100.0 & 45.0 & 60.0 & 81.3 & & & \\
\hline \multicolumn{11}{|l|}{ Education } \\
\hline 2 & 18.33 & 11.690 & 0.0 & 30.0 & 7.5 & 20.0 & 30.0 & \multirow{2}{*}{18.0} & \multirow{2}{*}{0.000} & \multirow{2}{*}{1.000} \\
\hline 3 & 16.67 & 22.509 & -10.0 & 40.0 & -2.5 & 15.0 & 40.0 & & & \\
\hline \multicolumn{11}{|c|}{ Implant outcomes } \\
\hline 2 & 21.94 & 13.142 & 8.3 & 40.0 & 8.3 & 20.8 & 35.0 & \multirow{2}{*}{5.0} & \multirow{2}{*}{-2.085} & \multirow{2}{*}{$0.037^{\star}$} \\
\hline 3 & -4.72 & 18.631 & -30.0 & 20.0 & -22.5 & -4.2 & 12.5 & & & \\
\hline \multicolumn{11}{|c|}{ Child support } \\
\hline 2 & -10.42 & 44.312 & -75.0 & 37.5 & -46.9 & -12.5 & 37.5 & \multirow{2}{*}{17.0} & \multirow{2}{*}{-0.163} & 0871 \\
\hline 3 & -12.50 & 31.623 & -50.0 & 37.5 & -40.6 & -12.5 & 9.4 & & & \\
\hline
\end{tabular}

${ }^{*}$ Significant difference $(p<0.05)$, Mann-Whitney test

and insecurities regarding the next steps of development. These results suggest that the percentages of QoL domains can be dynamic, changing as therapeutic goals are achieved and new challenges are faced.

However, the prospects of some parents were different from the group average. Therefore, the benefits obtained with CI may vary within a group studied, as there are several factors that influence the success of an intervention aimed at children using CI, such as auditory sensory deprivation time, number of remaining ganglion cells, specialized speech therapy, time of use of the electronic device, constant maintenance of the external component, and cognitive development ${ }^{(28)}$.

The low percentages in QoL domains related to family and the variability of results in the study group reflected on the performance of the speech therapist in clinic auditory (re)habilitation. This alone highlights the importance of a therapeutic work that can establish guidelines to advise parents on aspects that mostly require support; to lead to individual therapy; and to ensure the involvement of the family in the process as provider of relevant information and as a primary socialization source.

Time of CI use in this group of children was related to different areas of CCIPP according to their parents, as found in a previous study ${ }^{(29)}$. However, subgroups related to use of CI had higher percentages for communication, which shows that the shorter the time of CI use, the higher the recognition of parents about children's QoL improvement.
Parents of children with more than 24 months of use considered self-confidence as the most impacted domain.

This is certainly related to the fact that, soon after CI activation, the expectations of parents are great in relation to communication, which is the most obvious area for them. As the time of CI use increases, a more general view of their children development may assign a more relevant score to areas other than communication.

The analysis of hearing categories and QoL questionnaire showed a negative correlation with implant outcomes: as the hearing skill progresses, the percentage of implant outcomes decreases. This suggests that the audiologist must be aware of the unrealistic expectations of parents for immediate results or beyond what was obtained in therapeutic intervention. Possibly, as hearing skills develop, parents fail to report such important benefits.

A survey of 247 parents of children using CI showed that most parents claim that the decision-making related to $\mathrm{CI}$ is a difficult process that causes anxiety and stress but necessary for their children. The authors stressed that parents' decision cannot be based on certainty that the benefits will occur, but they confirmed that they created great expectations about the results ${ }^{(30)}$.

The comparative analysis between subgroups of hearing categories indicated difference only in the field of implant outcomes, with higher percentage in the group of hearing category 2 , that is, the more developed the auditory skills of the child, the lower the percentage in family-related QoL 
domains. Implant outcomes field addresses issues related to postsurgical expectations, in addition to the progress made in the first months of use of the device, justifying that the interference of $\mathrm{CI}$ in this area is reduced as the child progresses with hearing abilities.

Decision of use and implant process, from the CCIPP protocol, were considered at the time of application but have not been analyzed in this study, as they can only be measured qualitatively ${ }^{(11)}$. This brings about new and necessary opportunities of QoL study in children users of CI from the perspective of their families through CCIPP to study the above-mentioned fields more thoroughly.

To do so, one must ensure a level of effective participation of the family in qualification and rehabilitation programs for children using CI to obtain the information needed and, hence, better results.

We suggest the use of questionnaires that allow measuring the family's understanding of issues related to the use of CI as a means of guiding the speech during children's hearing (re)habilitation process.

\section{CONCLUSION}

From the parents' perspective, CI improves the QoL of their children, especially when it comes to self-confidence and social relations.

A negative correlation was found between well-being and happiness and social relations domains.

The time of use of CI interferes in communication (the shorter the time of use, the greater the percentage of QoL improvement) and hearing category in the field of implant outcomes (the more the hearing skills were developed, the lower the percentage of improved QoL).

*RPA collaborated with data collection, analysis and interpretation, literature review, and writing of the paper; CGM and MIVC performed data analysis and interpretation, literature, and paper review; ACMC conceived the initial idea of the study, designed the methodology, and oriented the study and paper review.

\section{REFERENCES}

1. Teixeira AR, Freitas CLR, Millão LF, Gonçalves AK, Becker Junior B, Vieira AF, et al. Relação entre deficiência auditiva, idade, gênero e qualidade de vida de idosos. Arq Int Otorrinolaringol. 2008;12(1):62-70.

2. Magalhães ATM, Goffi-Gomez MV, Jardim I, Tsuji RK, Brito Neto R, Bento RF. Adaptação de próteses auditivas no candidato ao implante coclear. Rev CEFAC. 2011;13(1):75-84.

3. Bevilacqua MC, Martinho-Carvalho AC, Costa Filho AO, Moret ALM. Implante Coclear. In: Fernandes FDM, Mendes BCA, Navas ALPGP, organizadores. Tratado de Fonoaudiologia. $2^{\mathrm{a}}$ ed. São Paulo: Roca; 2009. p. 220-31.

4. Vidas S, Hassan R, Parnes LS. Real-life performance considerations of four pediatric multi-channel cochlear implant recipients. J Otolaryngol. 1992;21(6):387-93.

5. Patrick DL, Edwards TC, Skalicky AM, Schink B, Topolski TD, Kushalnagar P, et al. Validation of a quality-of-life measure for deaf or hard of hearing youth. J Otolaryngol Head Neck Surg. 2011;145(1):137-45.
6. The WHOQOL Group. The World Health Organization Quality of Life assessment (WHOQOL): position paper from the World Health Organization. Soc Sci Med. 1995;41(10):1403-9.

7. Lin FR, Niparko JK. Measurig health-related quality of life after pediatric cochlear implantation: a systematic review. Int J Pediatr Otorhinolaryngol. 2006;70(10):1695-706.

8. Zhao F, Bai Z, Stephens D. The relationship between changes in selfrated quality of life after cochlear implantation and changes in individual complaints. Clinic Otolaryngol. 2008;33(5):427-34.

9. Warner-Czyz AD, Loy B, Tobey EA, Nakonezny P, Roland PS. Healthrelated quality of life in children and adolescents who use cochlear implants. Int J Pediatr Otorhinolaryngol. 2011;75(1):95-105.

10. Nunes T, Pretzlik U, Ilicak S. Validation of a parent outcome questionnaire from pediatric cochlear implantation. J Deaf Stud Deaf Educ. 2005;10(4):330-56.

11. Huttunen K, Rimmanen S, Vikman S, Virokannas N, Sorri M, Archbold S, et al. Parents' views on the quality of life of their children 2-3 years after cochlear implantation. Int J Pediatr Otorhinolaryngol. 2009;73(12):1786-94.

12. Nikolopoulos TP, Lloyd H, Archbold S, O'Donoghue GM. Pediatric cochlear implantation: the parents' perspective. Arch Otolaryngol Head Neck Surg. 2001;127(4): 363-7.

13. Incesulu A, Vural M, Erkam U. Children with cochlear implants: parental perspective. Otol Neurol. 2003;24(4):605-11.

14. Tye-Murray N. Foundations of aural rehabilitation: children, adults, and their family members. $3^{\text {nd }}$ ed. New York: Thomson Delmar Learning; 2009.

15. Bevilaqua MC, Formigoni GMP. Audiologia educacional: uma opção terapêutica para a criança deficiente auditiva. Carapicuíba: Pró-fono; 1997.

16. Bevilacqua MC, Tech EA. Elaboração de um procedimento de avaliação de percepção de fala em crianças deficientes auditivas profundas a partir de cinco anos de idade. In: Marchesan IQ, Zorzi JL, Gomes ICD, organizadores. Tópicos em Fonoaudiologia. São Paulo: Lovise; 1996. p. 411-33.

17. Geers A. Techniques for assessing auditory speech perception and lipreading enhancement in young deaf children. Volta Rev. 1994;96(5):85-96.

18. Archbold SM, Lutman ME, Gregory S, O'Neill C, Nikolopoulos TM. Parents and their deaf child: their perceptions three years after cochlear implantation. Deafness Educ Int. 2002:4(1):12-40.

19. Fortunato-Tavares T, Befi-Lopes D, Bento RF, Andrade CR. Children with cochlear implants: communication skills and quality of life. Braz J Otorhinolaryngol. 2012;78(1):15-25.

20. Percy-Smith L, Cayé-Thomasen P, Gudman M, Jensen JH, Thomsen J. Self-esteem and social well-being of children with cochlear implant compared to normal-hearing children. Int J Pediatr Otorhinolaryngol. 2008;72(7):1113-20.

21. Schorr EA, Roth FP, Fox NA. Quality of life of children with cochlear implants: perceived benefit and problems and the perception of single words and emotional sounds. J Speech Lange Hear Res. 2009;52(1):141-52.

22. Anmyr L, Larsson K, Olsson M, Freijd A. Strengths and difficulties in children with cochlear implants: comparing self-reports with reports from parents and teachers. Int J Pediatr Otorhinolaryngol. 2012;76(8):1107-12.

23. Sparreboom M, Leeuw AR, Snik AF, Mylanus EA. Sequential bilateral cochlear implantation in children: parent's perspective and device use. Int J Pediatr Otorhinolaryngol. 2012;76(3):339-44.

24. Edwards L, Hill T, Mahon M. Quality of life in children and adolescents with cochlear implants and additional needs. Int J Pediatr Otorhinolaryngol. 2012;76(6):851-7.

25. Damen GW, Krabbe PF, Archbold SM, Mylanus EA. Evaluation of the Parental Perspective instrument for pediatric cochlear implantation to arrive at a short version. Int J Pediatr Otorhinolaryngol. 2007;71(3):425-33.

26. Loy B, Warner-Czyz AD, Tong L, Tobey EA, Roland PS. The children speak: an examination of the quality of life of pediatric cochlear implant users. Otolaryngol Head Neck Surg. 2010;142(2): 247-53. 
27. O'Neill C, Lutman ME, Archbold SM, Gregory S, Nikolopoulos TP. Parents and their cochlear implanted child: questionnaire development to assess parental views and experiences. Int J Pediatr Otorhinolaryngol. 2004;68(2):149-60.

28. Bevilacqua MC, Moret ALM, Costa AO. Conceituação e indicação do implante coclear. In: Bevilacqua MC, organizadora. Tratado de audiologia. São Paulo: Livraria Santos; 2011. p. 407-25.
29. Huber M. Health-related quality of life of Austrian children and adolescents with cochlear implants. Int J Pediatr Otorhinolaryngol. 2005;69(8):1089-101.

30. Hyde M, Punch R, Komesaroff L. Coming to a decision about cochlear implantation: parents making choices for their deaf children. J Deaf Stud Deaf Educ. 2010;15(2):162-78. 